\title{
PENGARUH RELAKSASI BENSON TERHADAP TINGKAT INSOMNIA PADA LANSIA DI GRIYA USIA LANJUT ST. YOSEF SURABAYA
}

\author{
Wijar Prasetyo ${ }^{1,}$ Pandeirot M. Nancye ${ }^{2}$, Rismauli Pusparini Sitorus ${ }^{3}$ \\ STIKes William Booth Surabaya \\ wijar85@gmail.com
}

\begin{abstract}
ABSTRAK
Gangguan pemenuhan kebutuhan tidur sering dijumpai pada lansia adalah ketidakmampuan tidur pada saat seseorang seharusnya tidur, baik dalam hal lama maupun dalamnya tidur. Keluhan yang kerap kali dirasakan oleh lansia adalah kesukaran untuk memulai tidur, sering terbangun selama tidur, tidur cepat tetapi terlalu cepat bangun dan tidak dapat tidur kembali. Beberapa lansia yang menderita insomnia mengatasi masalah tidurnya dengan mengkonsumsi obat dimana obat dapat menyebabkan ketergantungan. Teknik non farmakologi untuk mengatasi insomnia salah satunya dengan cara relaksasi Benson. Penelitian ini bertujuan mengetahui pengaruh teknik relaksasi Benson terhadap tingkat insomnia. Desain penelitian yang digunakan adalah pra-eksperimental (one grup pre post design). Populasi berjumlah 21 responden dengan sampel 20 yang dipilih dengan teknik simple random sampling. Tingkat insomnia sebelum dilakukan relaksasi Benson didapatkan sebagian besar insomnia kategori keparahan moderat sebanyak 13 orang (65\%). Setelah dilakukan relaksasi Benson didapatkan sebagian besar dalam kategori subthreshold insomnia sebanyak 12 orang (60\%). Hasil uji Wilcoxon sign rank test dengan tingkat kemaknaan $a=0.05$ diperoleh nilai $\rho=0.000(\rho<a)$ yang berarti H1 diterima. Dapat disimpulkan bahwa ada pengaruh relaksasi Benson terhadap tingkat insomnia. Relaksasi Benson dapat menenangkan pikiran dan emosi, mengurangi ketegangan otot dan otak, sehingga tubuh menjadi relaks dan dapat tidur dengan nyaman dan rileks.
\end{abstract}

Kata kunci: Lansia, Insomnia, Relaksasi Benson

\begin{abstract}
Disorder of meeting the sleep needs often found in the elderly is the inability to sleep when a person is supposed to sleep, both in terms of length and depth of sleep. Complaints that are often felt by the elderly are the difficulty to start sleep, often wake up during sleep, sleep fast but wake up too quickly and cannot sleep again. Some elderly people who suffer insomnia overcome their sleep problems by taking drugs which can cause dependence. Non-pharmacological techniques to overcome insomnia one of them by Benson relaxation. This study aims to determine the effect of Benson's relaxation techniques on insomnia levels. The research design used pre-experimental (one group pre post design). The population used 21 respondents with a sample of 20 selected by simple random sampling technique. The level of insomnia prior to Benson's relaxation was found in most insomnia moderate severity categories of 13 people (65\%). After Benson's relaxation, it was found that most of the people in the subthreshold insomnia category were 12 people $(60 \%)$. Wilcoxon sign rank test results with significance level $a=0.05$ obtained value $\rho=0.000(\rho<a)$ which means $\mathrm{H} 1$ is accepted. It can be concluded that there is a Benson relaxation effect on insomnia levels. Benson's Relaxation can calm the mind and emotions, reduce muscle and brain tension, so that the body relaxes and can sleep comfortably and relaxed.
\end{abstract}

Keywords: Elderly, Insomnia, Benson's relaxation 


\section{PENDAHULUAN}

Menua atau menjadi tua suatu proses yang tidak dapat dihindari. Proses penuaan terjadi secara alamiah. Hal ini dapat menimbulkan masalah fisik, mental, social, ekonomi, psikologis. Menurut Effendi dan Makfudli (2009) yang menjelaskan bahwa lanjut usia (lansia) adalah seseorang yang usianya 65 tahun ke atas, sedangkan menurut Maryam (2008) lansia adalah seseorang yang telah mencapai usia 60 tahun ke atas. Dengan bertambahnya usia, secara umum akan menimbulkan perubahan pada lansia. Perubahan-perubahan pada lansia meliputi perubahan sistem panca indera, sistem integumen, sistem muskuloskeletal, sistem neurologis, sistem kardiovaskuler, sistem pulmonal, sistem endokrin, sistem renal dan urinaria, perubahan psikologis, perubahan sistem tubuh pada lansia bisa mempengaruhi kebutuhan tidur. Selain itu pengaruh proses penuaan juga menimbulkan berbagai masalah baik secara fisik, psikologis, maupun sosial ekonomi. Kemunduran psikologis yang sering dijumpai pada lansia antara lain insomnia, stres, depresi, ansietas, dimensia, dan delirium (Wayan, 2006).

Insomnia merupakan gangguan tidur yang banyak terjadi pada lansia. Sekitar $40 \%$ penderita insomnia adalah seseorang yang berusia lebih dari 60 tahun (Linden, 2008). Gangguan pemenuhan kebutuhan tidur yang sering dijumpai pada lansia adalah ketidakmampuan tidur pada saat seseorang seharusnya tidur, baik dalam hal lama maupun dalamnya tidur. Keluhan yang kerapkali disampaikan mereka adalah kesukaran untuk memulai tidur, atau sering terbangun selama tidur atau tidur cepat dan dalam, tapi terlalu cepat bangun pada dini hari kemudian tidak dapat tidur kembali (Anies, 2005). Beberapa lansia yang menderita insomnia mengatasi masalah tidurnya dengan mengkonsumsi obat. Lansia memilih jalan pintas untuk langsung meminum obat tidur tanpa melihat dampak dari obat tersebut. Setelah meminum obat tidur, tidur akan menjadi pulas, tetapi ketika bangun badan akan terasa lemas dan lesu. Terapi insomnia dapat dilakukan dengan cara farmakologi dan non farmakologi.
Terapi farmakologi seperti pemberian zolpidem, estazolam, nitrazepam, nitrazepam, triazolam, premotazim dan lain sebagainya. Selain harga obat yang cenderung mahal. Dampak penggunaan obat dalam jangka waktu yang panjang dapat membuat lansia menjadi ketergantungan.

Beberapa lansia di Griya Usia Lanjut St. Yosef Surabaya ada yang mengkonsumsi obat-obatan insomnia, sebagian lagi ada yang menganggap insomnia adalah hal sepele dan tidak perlu penanganan lebih lanjut. Sedangkan terapi non farmakologi diantaranya dengan menciptakan lingkungan kamar yang nyaman, olahraga teratur, menggunakan wewangian aromatherapy di kamar, mendengarkan musik sebelum tidur, menerapkan teknik relaksasi Benson sebelum tidur. Relaksasi Benson adalah teknik relaksasi yang diciptakan oleh Herbert Benson. Relaksasi Benson merupakan relaksasi yang menggabungkan antara teknik respon relaksasi dan sistem keyakinan individu/ faith factor (difokuskan pada ungkapan tertentu berupa nama-nama Tuhan, yang diucapkan berulang-ulang dengan ritme teratur disertai sikap pasrah (Benson \& Proctor, 2000 dalam Tetti \& Cecep, 2015).

Menurut World Health Organization (WHO), Indonesia dengan jumlah lansianya menduduki urutan ke-18. Berdasarkan data di Amerika kasus insomnia mencapai 25$35 \%$ dari populasi untuk insomnia jenis tersier (sementara), sedangkan untuk insomnia kronis mencapai 10\%-15\% (detik.com oleh Nurjanah, 2014). Sementara sumber lain (Depkes RI, 2010) memperkirakan prevalensi gangguan tidur pada lansia cukup tinggi yaitu 50\% pada tahun 2009. Selain itu diperkirakan tiap tahun $20 \%-40 \%$ orang dewasa dan lansia mengalami kesukaran tidur dan $17 \%$ diantaranya mengalami masalah serius (Yuda, 2007). Di propinsi Jawa Timur 3\% diantaranya mengalami gangguan yang serius (Yunita, 2009). Berdasarkan hasil studi pendahuluan di Griya Usia Lanjut St. Yosef Surabaya, didapatkan lansia yang tinggal di panti 147 orang, 21 diantaranya mengalami gangguan kesulitan tidur 
(insomnia) data tersebut didapatkan dari pengurus panti. Peneliti juga melakukan observasi 3 lansia dimana lansia itu terlihat matanya merah, sering menguap. Hasil wawancara, lansia mengatakan badan terasa pegal, tidak segar, bahkan 1 dari 3 lansia tersebut tidak mengikuti senam karena badannya lemas. Kemampuan fisik menurun karena kemampuan organ dalam tubuh yang menurun, seperti jantung, paruparu, dan ginjal. Penurunan kemampuan organ mengakibatkan daya tahan tubuh dan kekebalan tubuh turut terpengaruh (Prasadja, 2009). Kemampuan fisik lansia yang semakin menurun menjadi faktor penyebab lansia mengalami gangguan kesulitan tidur (insomnia). Selain factor usia dan kemampuan fisik yang menurun, penyebab gangguan sulit tidur atau insomnia diantaranya adalah stress, kecemasan, depresi. Beberapa lansia dari jumlah penderita insomnia mengatasi masalah tidurnya dengan mengkonsumsi obat. Ketergantungan pada obat tidur menyebabkan berkurangnya kewaspadaan, disertai pembicaraan yang melantur, gangguan ingatan, gangguan koordinasi sehingga dapat menimbulkan jatuh, kebingungan, gangguan pernafasan dan memperberat kerja ginjal.

Dalam kaitan antara manfaat istirahat dan tidur terhadap kesehatan fisik pada lansia seringkali dispelekan atau diabaikan. Istirahat dan tidur menjalankan sebuah fungsi pemulihan baik secara fisiologis maupun psikologis. Secara fisiologis tidur mengistirahatkan organ tubuh seseorang, menyimpan energi, menjaga irama biologis, dan memperbaiki keadaan mental. Sedangkan secara psikologis, tidur dapat mengurangi ketegangan dan meningkatkan perasaan sejahtera. Fungsi pemeliharaan ini sangat penting bagi lansia yang memerlukan banyak waktu untuk menyesuaikan diri terhadap perubahan (Jaime, 2007).

Menurut (Turana, 2007) dampak yang terjadi apabila seseorang tidak mampu mencukupi kebutuhan tidurnya, maka akan menimbulkan banyak perubahan diantaranya efek fisiologis yaitu stres, efek psikologis dapat berupa gangguan memori, rasa capai meningkat, gangguan berkosentrasi, kehilangan motivasi, efek fisik/ somatik, dapat berupa kelelahan, nyeri otot, tidak rileks, hipertensi, efek sosial kurang bisa bersosialisasi dengan orang disekitarnya. Hal ini perlu penanganan untuk mengatasi masalah insomnia di mana salah satunya dapat dilakukan dengan relaksasi Benson. Relaksasi akan bisa mengaktifkan dari syaraf parasimpatis yang menstimulasi turunnya semua fungsi yang dinaikkan oleh syaraf simpatis, dan menstimulasi naiknya semua fungsi yang diturunkan oleh syaraf simpatis. Masing-masing syaraf parasimpatis dan syaraf simpatis saling berpengaruh maka dengan bertambahnya salah satu aktivitas sistem yang satu akan menghambat atau menekan fungsi yang lain. Ketika seseorang mengalami gangguan tidur maka ada ketegangan pada otak dan otot sehingga dengan mengaktifkan syaraf parasimpatis dengan teknik relaksasi maka secara otomatis ketegangan berkurang sehingga seseorang akan mudah untuk masuk ke kondisi tidur (Utami, 1993).

Melihat akibat dari gangguan tidur pada lansia diatas diperlukan penanganan atau sikap yang tepat untuk mengatasinya. Berbagai cara dapat dilakukan untuk menurunkan insomnia pada lansia, sebenarnya keadaan susah tidur dapat diatasi dengan cara yang lebih aman. Cara menyembuhkan insomnia pada lanjut usia adalah dengan terapi non farmakologi diantaranya adalah dengan mempertahankan suhu yang nyaman dikamar tidur. Suara gaduh, cahaya dan temperatur dapat mengganggu tidur. Lansia sangat sensitive terhadap stimulus lingkungannya, menjalankan pola hidup yang sehat yaitu dengan menghindari atau meminimalkan minum kopi, teh, soda dan alkohol. Selain itu terapi non farmakologi juga dapat dilakukan dengan olahraga teratur, senam pada pagi hari, menggunakan aromatherapi dalam kamar, mendengarkan musik sebelum tidur, dan penerapan relaksasi Benson sebelum tidur. Benson memperkenalkan teknik relaksasi yaitu suat teknik pengobatan untuk menghilangkan nyeri dan dapat mengurangi ketegangan yang berhubungan dengan fisiologis tubuh. Menurut penelitian Aemilianus Mau (2010) 
mengatakan bahwa ada pengaruh yang signifikan penerapan relaksasi Benson terhadap insomnia pada lansia, responden yang tertangani sebanyak $90 \%$ relaksasi merupakan kebebasan mental dan fisik dari ketegangan stres. Seseorang akan tertidur jika ia merasa nyaman dan rileks. Teknik ini merupakan upaya untuk membantu tubuh segar kembali. Teknik relaksasi benson dapat dilakukan 2 kali sehari selama 5-10 menit (Tetti Solehati, 2015). Relaksasi Benson dipilih oleh peneliti karena merupakan relaksasi yang menggabungkan antara teknik respons relaksasi dan sistem keyakinan individu/ Faicth factor (difokuskan pada ungkapan tertentu berupa nama-nama Tuhan, atau kata yang memiliki makna yang menenangkan bagi individu tersebut). Untuk itu peneliti tertarik sejauh mana "Pengaruh relaksasi Benson terhadap tingkat insomnia pada lansia di Griya Usia Lanjut St. Yosef Surabaya

\section{METODE}

Desain penelitian merupakan rencana penelitian yang disusun sedemikian rupa sehingga peneliti dapat memperoleh jawaban terhadap pertanyaan penelitian (Setiadi, 2007). Rancangan penelitian yang digunakan dalam penelitian ini adalah bersifat pra experimental (one grup prepost design) dengan variabel independent relaksasi Benson dan variable dependent insomnia pada lansia.

Populasi dalam penelitian adalah seluruh lansia di Griya Lanjut Usia St. Yosef Surabaya yang mengalami insomnia sebanyak 21 orang dengan besar sampel yang digunakan sebanyak 20 lansia yag dipilih dengan teknik pengambilan sampel simple random sampling.

Instrument yang digunakan dalam pengambilan data penelitian menggunakan kuisioner checklist ISI (Insomnia Severity Index) dan setelah data dikumpulkan dilakukan uji Wilcoxon untuk mengetahui pengaruh relaksasi Benson terhadap tingkat insomnia pada lansia.

\section{HASIL}

Tingkat Insomnia Sebelum Dilakukan Relaksasi Benson.
Tabel 1 Tingkat Insomnia Sebelum Dilakukan Relaksasi Benson Terhadap Insomnia Pada Lansia

\begin{tabular}{clcc}
\hline No & Kategori & Jumlah & $\begin{array}{c}\text { Presentas } \\
\text { e }\end{array}$ \\
\hline $\mathbf{1}$ & $\begin{array}{l}\text { Tidak } \\
\text { signifikan } \\
\text { insomnia }\end{array}$ & 0 & $0 \%$ \\
$\mathbf{2}$ & $\begin{array}{l}\text { Subthreshol } \\
\text { d insomnia }\end{array}$ & 5 & $25 \%$ \\
$\mathbf{3}$ & $\begin{array}{l}\text { Keparahan } \\
\text { moderat }\end{array}$ & 13 & $65 \%$ \\
$\mathbf{4}$ & Parah & 2 & $10 \%$ \\
Total & & 20 & 100 \\
\hline
\end{tabular}

Berdasarkan Tabel didapatkan bahwa sebagian besar responden sebelum dilakukan terapi relaksasi Benson memiliki kriteria yaitu keparahan moderat sebanyak 13 orang $(65 \%)$.

Tingkat insomnia sesudah dilakukan relaksasi Benson.

Tabel 2 Tingkat Insomnia Sesudah Dilakukan Relaksasi Benson Terhadap Insomnia Pada Lansia

\begin{tabular}{clcc}
\hline No & Kategori & Jumlah & Presentase \\
\hline $\mathbf{1}$ & $\begin{array}{l}\text { Tidak } \\
\text { signifikan } \\
\text { insomnia }\end{array}$ & 4 & $20 \%$ \\
$\mathbf{2}$ & $\begin{array}{l}\text { Subthreshol } \\
\text { insomnia }\end{array}$ & 12 & $60 \%$ \\
$\mathbf{3}$ & $\begin{array}{l}\text { Keparahan } \\
\text { moderat }\end{array}$ & 4 & $20 \%$ \\
$\mathbf{4}$ & Parah & 0 & $0 \%$ \\
Total & $\mathbf{2 0}$ & $\mathbf{1 0 0}$ \\
\hline
\end{tabular}

Berdasarkan Tabel didapatkan data sebagian besar responden setelah dilakukan relaksasi Benson memiliki kriteria subthreshold insomnia sebanyak 12 orang $(60 \%)$.

Pengaruh Relaksasi Benson

Tabel 3 Tabulasi Silang Frekuensi Data Distribusi Pengaruh Relaksasi Benson Terhadap Tingkat Insomnia Pada Lansia. 


\begin{tabular}{|c|c|c|}
\hline $\begin{array}{r}\begin{array}{r}\text { Relaksasi } \\
\text { Benson }\end{array} \\
\text { Tingkat } \\
\text { Insomnia }\end{array}$ & Sebelum & Sesudah \\
\hline $\begin{array}{l}\text { Tidak } \\
\text { Signifikan } \\
\text { Insomnia }\end{array}$ & $0(0 \%)$ & $4(20 \%)$ \\
\hline $\begin{array}{l}\text { Subthreshold } \\
\text { insomnia }\end{array}$ & $5(25 \%)$ & $12(60 \%)$ \\
\hline $\begin{array}{l}\text { Keparahan } \\
\text { moderat }\end{array}$ & $13(65 \%)$ & $4(20 \%)$ \\
\hline Parah & $2(10 \%)$ & $0(0 \%)$ \\
\hline \multicolumn{3}{|c|}{ Hasil Uji Wilcoxon: $\mathrm{p}=.000$} \\
\hline
\end{tabular}

Berdasarkan tabel dapat diketahui bahwa hasil penelitian di Griya Usia Lanjut St. Yosef Surabaya responden yang mengalami insomnia dengan kategori parah sebelum dilakukan relaksasi Benson sebanyak 2 orang (10\%), insomnia dengan kategori keparahan moderat sebanyak 13 orang (65\%), insomnia dengan kategori subthresold insomnia sebanyak 5 orang (25\%), dan tidak ada yang termasuk daam kategori tidak signifikan insomnia. Kemudian setelah dilakukan relaksasi Benson ditemukan tidak ada responden yang masuk dalam insomnia kategori parah, sedangkan pada insomnia kategori keparahan moderat mengalami penurunan menjadi 4 orang responden (20\%), subthresold insomnia mengalami peningkatan menjadi 12 orang (65\%), dan kategori tidak signifikan insomnia mengalami peningkatan sebanyak 4 orang (20\%). Hasil analisa dari uji wilcoxon diketahui bahwa nilai $\mathrm{p}<0,05$ sehingga dapat dikatakan bahwa ada pengaruh relaksasi Benson terhadap tingkat insomnia pada lansia.

\section{PEMBAHASAN}

\section{Tingkat Insomnia Sebelum Dilakukan Relaksasi Benson}

Pada hasil penelitian yang berdasarkan tabel 1 tentang distribusi data tingkat insomnia sebelum dilakukan relaksasi Benson, sebagian besar responden mengalami insomnia kategori keparahan moderat sebanyak 13 orang (65\%). Insomnia merupakan gangguan tidur yang muncul pada kondisi dan situasi dimana seharusnya ada kesempatan untuk tidur. Gangguan tidur yang dimaksud dapat berupa kesulitan untuk memulai tidur, tidak bisa tidur dengan nyenyak, atau bangun terlalu awal, Ellyana Linden, dkk (2008). Pemenuhan kebutuhan tidur setiap orang berbeda-beda, terutama pada usia lanjut yang lebih sering mengalami gangguan istirahat tidur. Menurut Perry Potter (2009) beberapa faktor yang mempengaruhi istirahat tidur yaitu faktor eksternal meliputi lingkungan, respon terhadap penyakit, gaya hidup, depresi, stress, pengaruh makanan dan obat-obatan, status perkawinan, sedangkan faktor internal meliputi jenis kelamin, usia, pendidikan. Berdasarkan teori diatas dapat diketahui bahwa ada banyak faktor yang saling berhubungan sehingga dapat menyebabkan insomnia pada lansia.

Berdasarkan hasil penelitian yang terdapat pada diagram memberikan gambaran bahwa 20 responden yang mengalami insomnia sebagian besar yaitu 13 orang $(65 \%)$ berumur $>75$ tahun. Hasil penelitian ini didukung oleh teori Darmojo (2005), umur merupakan salah satu faktor yang apat mempengaruhi kesehatan seseorang. Pola tidur yang normal mulai berubah sesuai bertambahnya usia, akibat reduksi saraf yang mempengaruhi gelombang tidur atau oleh karena defisit sistem saraf pusat yang menyebabkan berkurangnya reaksi terhadap alarm ekstrinsik dan disfungsi "biorhythm" serta berkurangnya pengeluaran substansi melatonia. Hal ini sesuai dengan kondisi lansia yang semakin bertambahnya umur membuat lansia mengalami penurunan fungsi organ, salah satunya penurunan sel saraf otak yang menyebabkan reduksi kerja saraf yang berpengaruh pada penurunan perasaan yang merangsang untuk tidur. Hal ini secara fisiologis dapat menyebabkan kualitas dan kuantitas tidur lansia menurun bahkan dapat menyebabkan gangguan pemenuhan tidur seperti insomnia.

Apabila dihubungkan dengan distribusi responden berdasarkan jenis kelamin pada diagram 5.2 yang 
menunjukkan bahwa dari 20 responden yang mengalami insomnia adalah perempuan sebanyak 15 orang (75\%). Hasil penelitian ini sejalan dengan teori Nugroho (2010) prevalensi insomnia lebih tinggi pada wanita dibandingkan pria. Wanita lebih memiliki kemungkinan untuk mengalami mimpi buruk, kesulitan tidur, dan sering terbangun dibandingkan pria. Perempuan secara psikologis memiliki mekanisme koping yang lebih rendah dibandingkan dengan laki-laki dalam mengatasi suatu masalah, dengan adanya gangguan secara fisik maupun secara psikologis tersebut maka wanita akan mengalami suatu kecemasan, jika kecemasan itu berlanjut maka akan mengakibatkan seseorang lansia lebih sering mengalami kejadian insomnia dibandingkan dengan laki-laki. Hal ini menunjukkan kesesuaian antara fakta dan teori dimana perempuan lebih cenderung mengalami insomnia. Hal ini disebabkan karena perempuan sering mengalami depresi atau stres dibanding laki-laki. Secara psikososial perempuan lebih banyak mengalami tekanan daripada laki-laki. Banyak faktor yang membuat lansia cemas, diantaranya yaitu munculnya rasa tersisih, tidak dibutuhkan lagi, ketidak iklhasan menerima kenyataan, kematian pasangan merupakan sebagian kecil dari keseluruhan perasaan yang tidak enak yang harus dihadapi lansia. Kecemasan yang dialami ini dapat menyebabkan lansia mengalami gangguan tidur.

Selanjutnya menurut Petti Lubis (2009) prevalensi insomnia lebih banyak terjadi pada wanita daripada laki-laki hal ini dipengaruhi oleh hormon. Hormon yang dimaksud adalah estrogen. Dimana pada wanita hormon estrogen berperan untuk mengatur siklus menstruasi dan kehamilan. Hormon ini dapat mempengaruhi zat kimia di otak yang berkaitan dengan stres dan pola tidur. Dimana kadar hormon estrogen yang tinggi dapat membantu pola tidur yang baik, sedangkan kadar hormon estrogen yang rendah dapat memperburuk pola tidur yang dialami. Dari hal di atas diketahui bahwa semua responden yang mengalami insomnia adalah wanita yang tegolong menopause. Dimana pada saat menopause kadar estrogen berfluktuasi, sehingga hal inilah yang menyebabkan wanita lebih banyak menderita insomnia dibandingkan laki-laki.

Berdasarkan data demografi diketahui bahwa dari 20 responden yang mengalami insomnia, terdapat sebanyak 10 orang $(53 \%)$ yang tamat SD. Menurut teori Darmojo (2005) tingkat pendidikan, merupakan salah satu faktor sosiokultural yang bisa mempengaruhi insomnia. Tingkat pendidikan yang tinggi bisa memungkinkan individu untuk mengakses dan memahami informasi tentang kesehatan sehingga pasien memiliki pengetahuan untuk memilih strategi dalam mengatasi insomnia. Hal ini menunjukkan kesesuaian antara fakta dan teori, semakin tinggi tingkat pendidikan akan membuat seseorang semakin mudah berfikir rasional. Sebaliknya semakin rendah tingkat pendidikan maka akan semakin sulit bagi seseorang untuk mendapatkan pikiran yang rasional dan logis. Oleh sebab itu dalam pelaksanaan relaksasi Benson, peneliti menggunakan kalimat yang semudah mungkin dapat dimengerti oleh responden sehingga responden dapat mengetahui, memahami, dan mengaplikasikan relaksasi Benson.

Berdasarkan data status responden terdapat sebanyak 11 orang (55\%) berstatus janda. Hasil penelitian yang menunjukkan responden yang mengalami insomnia dengan kategori keparahan moderat sebagian besar lansia yang berstatus janda. Hal ini didukung oleh teori Darmojo (2005) keberadaan pasangan hidup akan mengurangi tingkat kecemasan yang dialami lansia, karena pasangan hidup dapat menjadi sumber koping yang adekuat dalam menghadapi stressor. Hal ini menunjukkan kesesuaian fakta dengan teori, kehilangan pasangan lebih sering terjadi pada populasi perempuan daripada laki-laki. Kesepian yang dialami lansia yang berstatus janda dapat menyebabkan insomnia, mereka merasa kehilangan seseorang ketika harus tidur sendiri setelah sekian tahun menikah. Hal ini dapat menyebabkan lansia mengalami ketidaknyamanan saat tidur. 


\section{Tingkat Insomnia Setelah Dilakukan Relaksasi Benson}

Berdasarkan tabel 2 responden yang mengalami insomnia sebagian besar adalah subthreshold insomnia sebanyak 12 orang (60\%). Hasil tersebut menunjukkan bahwa terjadi penurunan tingkat insomnia setelah dilakukan relaksasi Benson. Menurut Benson dan Proctor (2000) dalam Tetti Solehati (2015), relaksasi Benson merupakan relaksasi yang menggabungkan antara teknik respons relaksasi dan sistem keyakinan individu/ faith factor (difokuskan pada ungkapan tertentu berupa nama-nama Tuhan, atau kata yang memiliki makna menenangkan bagi pasien itu sendiri) yang diucapkan berulang-ulang dengan ritme teratur disertai sikap pasrah. Relaksasi ini bertujuan untuk mengatasi atau mengurangi kecemasan, menurunkan ketegangan otot dan tulang, serta secara tidak langsung dapat mengurangi nyeri dan menurunkan ketegangan yang berhubungan dengan fisiologis tubuh (Kozier\& Olivieri, 1996 dalam Tetti Solehati, 2015).

Berdasarkan hasil penelitian dan dikaitkan dengan teori di atas menunjukkan bahwa ada pengaruh yang signifikan penerapan relaksasi Benson terhadap insomnia pada lansia di Griya Usia Lanjut St. Yosef, responden yang mengalami penurunan tingkat insomnia sebanyak 15 orang. Hal ini disebabkan karena relaksasi Benson melatih responden agar dapat mengondisikan dirinya untuk mencapai suatu keadaan rileks. Juga pelaksanaan relaksasi Benson selama 2 minggu dilakukan selama 10 mnit, dan diterapkan 2 kali sehari dengan benar dan tepat dapat membuat rileks responden. Namun keberhasilan relaksasi Benson yang penulis lakukan pada responden tidak lepas dari kepatuhan responden dimana responden harus benar-benar percaya bahwa tindakan ini dapat membantu proses penurunan insomnia yang dialami.

\section{Pengaruh Relaksasi Benson Terhadap Tingkat Insomnia}

Hasil pengumpulan data mengenai perbandingan atau perbedaan antara data pre dan post serta hubungan dari kedua data yang mana secara khusus memberikan gambaran dalam suatu hasil penelitian,berdasarkan tabulasi silang tabel 3 dapat diketahui bahwa responden yang mengalami insomnia sebelum dilakukan relaksasi Benson didapatkan insomnia kategori parah sebanyak 2 orang (10\%), keparahan moderat 13 orang (65\%), subthreshold insomnia 5 orang $(25 \%)$, tidak signifikan insomnia 0 orang $(0 \%)$, dan setelah dilakukan relaksasi Benson didapatkan responden yang mengalami insomnia parah $0(0 \%)$, keparahan moderat 4 orang (20\%), subthreshold insomnia 12 orang $(60 \%)$, tidak signifikan insomnia 4 orang $(20 \%)$. Berdasarkan hasil uji statistic Wilcoxon Pengaruh Relaksasi Benson Terhadap Tingkat Insomnia Pada Lansia di Griya Usia Lanjut St. Yosef Surabaya diketahui bahwa nilai $\mathrm{p}=0.000$ yaitu $\mathrm{p}<0.05$ dengan demikian $\mathrm{H} 0$ ditolak $\mathrm{H} 1$ diterima yang memiliki arti ada pengaruh terapi relaksasi Benson terhadap tingkat insomnia pada lansia di Griya Usia Lanjut St. Yosef Surabaya.

Hasil penelitian ini sejalan dengan Potter dan Perry (2005) bahwa seseorang akan tertidur jika dirinya merasa nyaman dan rileks. Hal ini dapat dicapai melalui latihan teknik relaksasi. Relaksasi merupakan kebebasan mental dan fisik dari ketegangan dan stres. Teknik relaksasi memberikan kesempatan kepada individu untuk dapat kontrol diri dan lingkungan. teknik ini merupakan upaya pencegahan untuk membantu tubuh segar kembali dan bergenerasi setiap hari. Klien yang menggunakan relaksasi ini dengan berhasil mengalami beberapa perubahan baik fisiologis maupun perilaku.

Pikiran relaksasi merupakan pengaktifan dari syaraf parasimpatis yang menstimulais turunnya semua fungsi yang dinaikkan oleh sistem syaraf simpatis, dan menstimulasi naiknya semua fungsi yang diturunkan oleh syaraf simpatis. Masingmasing parasimpatis dan simpatis saling berpengaruh maka dengan bertambahnya salah satu aktivitas sistem yang satu, akan menghambat atau menekan fungsi yang lain. Ketika seseorang mengalami gangguan tidur maka ada ketegangan pada otak dan otot sehingga dengan mengaktifkan syaaf parasimpatis dengan tenkik relaksasi 
Benson maka secara otomatis ketegangan berkurang sehingga seseorang akan mudah untuk masuk ke kondisi tidur. Pada saat tubuh dan pikiran rileks, secara otomatis ketegangan yang seringkali membuat otototot mengencang akan diabaikan (Utami, 1993).

Penerapan relaksasi Benson ini cukup efektif untuk memperpendek waktu dari mulai merebahkan hingga tertidur. Saat seseorang mengalami kecemasan, saraf yang bekerja adalah sistem saraf simpatis. Sedangkan pada saat relaksasi, yang bekerja adalah sistem saraf parasimpatis, sehingga relaksasi dapat menekan rasa cemas dengan cara berbalasan. Hal ini dapat mengurangi rasa cemas yang dialami seseorang. Relaksasi Benson dapat menenangkan pikiran dan fisik seseorang, mengurangi tekanan mental, fisik, dan juga emosi, sehingga lansia tidak merasa cemas dan tegang. Hal ini membuktikan bahwa relaksasi Benson yang dilakukan dapat membuat lebih relaks sehingga kesulitan tidur dapat diatasi dengan relakasasi ini. Apabila seseorang mudah tertidur juga dapat mengurangi stress tentang kebiasaan sulit mengawali tidur.

\section{SIMPULAN DAN SARAN}

Berdasarkan hasil penelitian dapat disimpulkan bahwa terdapat pengaruh relaksasi Benson terhadap insomnia pada lansia di Griya Usia Lanjut St. Yosef Surabaya setelah dilakukan Uji Wilcoxon didapatkan hasil $\mathrm{p}=0.000$.

Berdasarkan kesimpulan di atas, diharapkan penelitian ini menjadi dasar bagi peneliti selanjutnya untuk melakukan penelitian yang serupa dengan mengkombinasikan musik atau dengan aromatherapy untuk mengatasi insomnia lansia pada lansia.

\section{DAFTAR PUSTAKA}

Anies, A. 2005. Insomnia Gangguan Sulit Tidur. Jakarta: Kanisius.

Alimul, Aziz. 2007. Metode Penelitian Dan
Teknik $\quad$ Dasar
Jakarta:Salemba Medika

Bandiyah, Siti. 2009. Lanjut Usia Dan Keperawatan Gerontik. Yokyakarta: Nuha Medika.

Charles, M. Morin. 2003. Insomnia Saverity Index Arthritis Care and Resevartif Volume 49. Jakarta: Salemba Medika.

Darmojo. 2005. Proses Menua dan Implikasi Kliniknya. Buku Ajar Penyakit Ilmu Dalam Jilid 1 (Edisi 5). Fakultas Kedokteran UI: Jakarta.

Depkes RI. 2010. Klarifikasi Lansia. Jakarta: Dinas Kesehatan Republik Indonesia.

Effendi \& Makfudli. 2009. Proses Мепиа. Jakarat: EKG.

Jaime. 2007. Lansia Masa Kini dan Mendatang. Jakarta: EGC.

Linden Ellyana, dkk. 2008. Serba - serbi Gangguan Kesehatan pada Lanjut Usia. Surabaya: Pusat informasi Obat dan Layanan Kefarmasian (PIOLK) Universitas Surabaya.

Maryam, Siti dkk. 2008. Mengenal Usia Lanjut Dan Perawatannya. Jakarta: Salemba Medika.

Mau, Aemilianus. 2012. Pengaruh Penerapan Teknik Relaksasi Benson Terhadap Gangguan Tidur (Insomnia) Pada Lansia di UPT Panti Sosial Penyantunan Lanjut Usia Budi Agung Kupang. http://jrpatrick.stikskpg.ac.id/dspace/ keperawanan/123456789/289/2/MA U\%20AEMILIANUS-FPS.PDF.

Diakses Senin, 23 November 2015. Jam 09.00 WIB.

Nugroho. 2010. Keperawatan Gerontik dan Geriatrik. Jakarta: Penerbit Buku Kedokteran: EGC. 
Olivia, Donna. 2010. Hubungan Antara Integrity Dengan Psychological Well- Being lanjut Usia. Jakarta: Universitas Indonesia http://repostory.uinjkt.ac.id/dspace/di tstream/123456789/3791/1/DONNA \%20OLIVIA-FTP.PDF. Diakses Jumat, 13 Januari 2016. Jam 17.00 WIB.

Perry \& Potter. 2009. Buku Ajar Fundamental Keperawatan: Konsep, Proses, dan dan Praktik. Jakarta: EGC.

Petty, Lubis. 2009. Insomnia dan Penyebabnya. Bandung: Sinar Baru Algesindo.

R. Siti Maryam, dkk. 2011. Terapi Modalitas Keperawatan pada Klien Psikogeriatrik. Jakarta: Salemba Medika.

Prasadja. 2009. Buku Ajar Ilmu Penyakit Dalam. Jakarta: EKG.

Tetti Solehati \& Cecep Eli Kosasih. 2015. Konsep \& Aplikasi Relaksasi Dalam Keperawatan Maternitas. Bandung: PT. Refika Aditama.
Turana. 2007. Mengenal Insomnia dan Terapi Insomnia. Jakarta: Salemba Medika.

Utami, M. S. 1993. Prosedur Relaksasi. Fakultas psikologi UGM: Yogyakarta.

Wayan, S. A. 2006. Depresi dan Tingkat Psikologi. Jakarta: PT RINEKACIPTA.

Yuda. A, P. 2007. Prevalensi Data-Data Yang Mengalami Insomnia Indonesia http//lib.ugm.ac.id/data/pubdata/relak sasi.html. Diakses Selasa, 24 November 2016. Pukul 10.00 WIB.

Yunita, A. 2009. Data-data Insomnia Lansia. Jakarta: Universitas Indonesia.

http://koranbogor.com/sosialbudaya/12/12/2011/lanjut-usiainsomnia-prevalensi.html. Diakses Selasa, 24 November 2016. Pukul 11.00 WIB. 